\title{
Microbacterium lacusdiani sp. nov., a phosphate-solubilizing novel actinobacterium isolated from mucilaginous sheath of Microcystis
}

\author{
Bing-Huo Zhang ${ }^{1,2}$, Nimaichand Salam ${ }^{2}$, Juan Cheng, ${ }^{1,2}$, Han-Quan Li ${ }^{1}$, Jian-Yuan Yang1, Dai-Ming Zha ${ }^{1}$, \\ Qi-Gen Guo ${ }^{1}$ and Wen-Jun $\mathrm{Li}^{2,3}$
}

A novel actinobacterium, designated strain JXJ $\mathrm{CY} 01^{\top}$, was isolated from a mucilaginous sheath of Microcystis aeruginosa FACHB-905 collected from Lake Dianchi, south-west China. Taxonomic position of the isolate was determined by polyphasic approaches. Strain JXJ CY $01^{\top}$ shared 16S rRNA sequence similarities of 98.9 and $98.0 \%$ with Microbacterium marinilacus YM11-607 ${ }^{\top}$ and Microbacterium paludicola US15 ${ }^{\top}$, and less than $98 \%$ with other members of the genus Microbacterium.

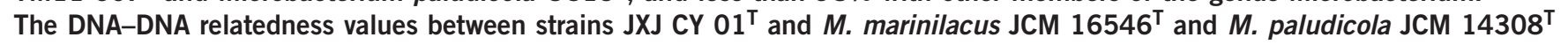
were $53.5 \pm 1.4$ and $53.8 \pm 2.1 \%$, respectively. L-Ornithine was detected in the cell wall, and rhamnose, galactose, glucose, arabinose, fucose and mannose as signature sugars in the whole-cell hydrolysates. Other chemotaxonomic characteristics determined were MK-12 and MK-11 as predominant menaquinones, anteiso- $C_{15: 0}$, iso- $C_{16: 0}$, anteiso- $C_{17: 0}$ and iso- $C_{17: 0}$ as major cellular fatty acids ( $>10 \%$ ), and diphosphatidylglycerol, phosphatidylglycerol, an unidentified glycolipid and two unidentified phospholipids as the polar lipids. The DNA G+C content was $70.4 \mathrm{~mol} \%$. On the basis of the above taxonomic data, strain JXJ $\mathrm{CY} 01^{\top}$ is determined to represent a novel species of the genus Microbacterium, for which the name Microbacterium lacusdiani sp. nov. is proposed. The type strain is JXJ CY $01^{\top}\left(=\right.$ KCTC $\left.29655^{\top}=\mathrm{DSM} 29188^{\top}\right)$. The type strain JXJ CY $01^{\top}$ can solubilize both insoluble inorganic (calcium phosphate) and organic phosphate (L- $\alpha$-phosphatidylcholine) and is possibly one of the mechanism for enhancement of growth of $M$. aeruginosa FACHB-905.

The Journal of Antibiotics (2017) 70, 147-151; doi:10.1038/ja.2016.125; published online 19 October 2016

\section{INTRODUCTION}

Eutrophication caused by dumping of agricultural, domestic and industrial waste is a major reason behind harmful cyanobacterial blooms in more than $60 \%$ of the freshwater lakes in China. ${ }^{1,2}$ In Lake Dianchi, the largest lake in Yunnan Province, southwestern China and a vital source of water of Kunming City (the capital of Yunnan Province), Microcystis especially Microcystis aeruginosa was found to be the main algal blooms during warm seasons. ${ }^{3}$ Mucilaginous investment of Microcystis provides an excellent ecological niches for many other bacteria, including Alphaproteobacteria, Betaproteobacteria, Gammaproteobacteria, Actinobacteria and Bacteroidetes. ${ }^{4-6}$ Mutualism is one of the main reasons of this coexistence of Microcystis and bacteria, whereby the bacteria provide the raw materials to Microcystis and are replenished with nutrient and safer environments. $^{7-12}$

During a study of bacteria associated with mucilage released by M. aeruginosa FACHB-905 (MAF) collected from Lake Dianchi, a novel actinobacterium designated strain JXJ CY $01^{\mathrm{T}}$ belonging to the genus Microbacterium was isolated. This manuscript described the polyphasic characterization of the novel strain. The manuscript also discusses the phosphate-solubilizing property of the strain in light to its in vitro interaction with MAF.

\section{MATERIALS AND METHODS}

Isolation and maintenance of strain

MAF culture was incubated in HGZ media ${ }^{13}$ under illumination of 30-50 $\mu \mathrm{mol}$ photon per $\mathrm{m}^{2}$ per second in a 12-h light/dark cycle till the color turned into green. About $0.2 \mathrm{ml}$ of this green algal culture broth was spread on International Streptomyces Project (ISP) medium 2 agar plates, ${ }^{14}$ and incubated at $28^{\circ} \mathrm{C}$ for 5 days. Bacterial colonies were selected and repeatedly streaked on the same medium to obtain pure cultures. Purified strain was maintained on ISP 2 medium at $28{ }^{\circ} \mathrm{C}$ and stored as glycerol suspensions $(30 \%, \mathrm{v} / \mathrm{v})$ at $-80^{\circ} \mathrm{C}$.

\section{Phenotypic characterization}

Morphology was observed using a light microscope (BX43; Olympus, Tokyo, Japan) and a scanning electron microscope (QUANTA200; FEI, Hillsboro, OR, USA). Gram staining was done by using the standard Gram's staining procedure. Growth at various $\mathrm{pH}(4.0-11.0)$, temperatures $\left(4-50{ }^{\circ} \mathrm{C}\right)$ and $\mathrm{NaCl}$ contents $(0-10 \%, \mathrm{w} / \mathrm{v})$ were tested according to the method described by

\footnotetext{
${ }^{1}$ College of Life Science, Jiujiang University, Jiujiang, PR China; ${ }^{2}$ State Key Laboratory of Biocontrol and Guangdong Provincial Key Laboratory of Plant Resources, School of Life Sciences, Sun Yat-Sen University, Guangzhou, PR China and ${ }^{3}$ Key Laboratory of Biogeography and Bioresource in Arid Land, Xinjiang Institute of Ecology and Geography, Chinese Academy of Sciences, Ürúmqi, PR China

Correspondence: Professor W-J Li, State Key Laboratory of Biocontrol and Guangdong Provincial Key Laboratory of Plant Resources, School of Life Sciences, Sun Yat-Sen University, No 135, Xinggang West Road, Guangdong, Guangzhou 510275, PR China.

E-mail: liwenjun3@mail.sysu.edu.cn

Received 25 April 2016; revised 27 August 2016; accepted 5 September 2016; published online 19 October 2016
} 
$\mathrm{Xu}$ et al. ${ }^{15}$ using ISP 2 as the basal growth medium. Catalase activity was assessed from the bubble production on addition of a drop of $3 \%(\mathrm{v} / \mathrm{v}) \mathrm{H}_{2} \mathrm{O}_{2}$. Oxidase activity was determined according to Kovacs. ${ }^{16}$ Other phenotypic characteristics were determined according to Goodfellow ${ }^{17}$ and Williams et al. ${ }^{18}$ Enzyme activities were measured by using the commercial API ZYM system (bioMérieux, Marcy l'Etoile, France). Assimilation of various substrates was determined using Biolog GN III Micro Plate assays as described by the manufacturer.

\section{Chemotaxonomic analysis}

The peptide subunit of peptidoglycan and whole-cell sugars was determined according to the procedures described by Hasegawa et al. ${ }^{19}$ and Tang et al. ${ }^{20}$ Polar lipids were extracted as described by Minnikin et al. ${ }^{21}$ and analyzed according to the method described by Collins and Jones. ${ }^{22}$ Menaquinones were extracted as described by Collins et al. ${ }^{23}$ and analyzed using HPLC. ${ }^{24}$ Cellular fatty acids were extracted, methylated and analyzed by using the microbial identification system (Sherlock Version 6.1; MIDI database: TSBA6). ${ }^{25}$ Biomass for fatty acid analysis was obtained from cells grown on tryptone soy agar (TSA; Difco, Berkeley, CA, USA) at $28^{\circ} \mathrm{C}$ for 4 days. The $\mathrm{G}+\mathrm{C}$ content of genomic DNA of strain JXJ CY $01^{\mathrm{T}}$ was measured using HPLC. ${ }^{26}$

\section{Phylogenetic analysis}

The genomic DNA extraction, PCR amplification and sequencing of 16S rRNA gene were performed according to $\mathrm{Xu}$ et al. ${ }^{15}$ The almost-complete $16 \mathrm{~S}$ rRNA gene sequence of the strain was aligned with sequences of the most closely related taxa using CLUSTAL X version 1.83. ${ }^{27}$ Phylogenetic dendrograms were generated by the neighbor-joining, ${ }^{28}$ maximum-likelihood ${ }^{29}$ and maximum-parsimony ${ }^{30}$ tree making algorithms using the software package MEGA version 5.0. ${ }^{31}$ The topologies of the phylogenetic trees were evaluated by using bootstrap analysis of Felsenstein ${ }^{32}$ with 1000 replicates. The genomic DNA-DNA relatedness between strain JXJ CY $01^{\mathrm{T}}$ and closely related members of the genus Microbacterium (M. marinilacus JCM $16546^{\mathrm{T}}$ and M. paludicola JCM $14308^{\mathrm{T}}$ ) were performed as described by Ezaki et al. ${ }^{33}$

\section{Phosphate solubilization}

Phosphate solubilization was determined by measuring the amount of soluble phosphorus released from an insoluble phosphate-containing growth (PG) medium (glucose $10.0 \mathrm{~g},\left(\mathrm{NH}_{4}\right)_{2} \mathrm{SO}_{4} 0.5 \mathrm{~g}, \mathrm{MgSO}_{4} \cdot 7 \mathrm{H}_{2} \mathrm{O} 0.3 \mathrm{~g}, \mathrm{NaCl} 0.3 \mathrm{~g}, \mathrm{KCl}$ $0.3 \mathrm{~g}, \mathrm{FeSO}_{4} \cdot 4 \mathrm{H}_{2} \mathrm{O} \quad 0.036 \mathrm{~g}, \mathrm{MnSO}_{4} \cdot 4 \mathrm{H}_{2} \mathrm{O} \quad 0.03 \mathrm{~g}, \mathrm{Ca}_{3}\left(\mathrm{PO}_{4}\right)_{2} \quad 10.0 \mathrm{~g}$ or $\mathrm{L}-\alpha$-phosphatidylcholine $2.0 \mathrm{~g}$, distilled water 1 liter, $\mathrm{pH}$ 7.0). Aliquots of JXJ $\mathrm{CY} 01^{\mathrm{T}}$ culture suspension were inoculated into PG medium to a final cellular concentration of $\sim 1 \times 10^{6} \mathrm{CFU} \mathrm{m}^{-1}$ and incubated for 6 days $\left(28^{\circ} \mathrm{C}, 180\right.$ r.p.m.). Uninoculated PG medium served as control. The cultures were harvested by centrifugation at $4860 \mathrm{~g}$ for $20 \mathrm{~min}$. Soluble phosphorus in culture supernatant was estimated using a colorimetric method as described below: Reaction mixture containing $5 \mathrm{ml}$ supernatant, $0.1 \mathrm{ml}$ 2,4-dinitrophenol solution $(0.011 \mathrm{M})$ and $5 \mathrm{ml} \mathrm{Mo}$-Sb reagent solution were adjusted to a final volume of $50 \mathrm{ml}$ with distilled water, briefly mixed and kept incubated at $25^{\circ} \mathrm{C}$ for $30 \mathrm{~min}$. Absorbance of the reaction mixture was monitored at $700 \mathrm{~nm}$ against a standard of potassium phosphate. The Mo-Sb reagent solution contained (per liter) sulfuric acid $2.87 \mathrm{~mol}$, ammonium molybdate $8.1 \mathrm{mmol}$, antimonyl potassium tartrate $1.5 \mathrm{mmol}$ and ascorbic acid $85.2 \mathrm{mmol}$ (added into the solution just before use). Concentration of the soluble phosphorus in the culture media was calculated based on the following equation: $\mathrm{X}=\mathrm{P} \times V 1 / V 2 \times K$, where $\mathrm{X}$ represent soluble phosphorus in the culture media; $\mathrm{P}$ the soluble phosphorus calculated for a reaction mixture; $V 1$ the total volume of reaction mixture; $V 2$ the volume of culture supernatant added in the reaction mixture, and $K$ the dilution ratio used for measuring the absorbance.

\section{Effect on the growth of MAF by co-culturing with strain JXJ CY $01^{\mathrm{T}}$ under in vitro condition}

Effect of strain JXJ CY $01^{\mathrm{T}}$ on the growth of MAF was determined by co-culturing them in three different media: HGZ broth ${ }^{13}$ and modified HGZ media $\left(\mathrm{KH}_{2} \mathrm{PO}_{4}\right.$ replaced with $\mathrm{Ca}_{3}\left(\mathrm{PO}_{4}\right)_{2}$ and L- $\alpha$-phosphatidylcholine respectively) as detailed below. Aliquots of pure cultures of MAF $\left(2 \times 10^{6} \mathrm{CFU} \mathrm{ml}^{-1}\right)$ were inoculated onto the three media. Each of these media was then co-inoculated with three different inoculums of strain JXJ CY $01^{\mathrm{T}}\left(0.2 \times 10^{9}\right.$, $1 \times 10^{9}$ and $5 \times 10^{9} \mathrm{CFU} \mathrm{ml}^{-1}$ ). For the control, bacterial cell suspension was replaced with sterilized water. The co-cultures were incubated under illumination of 30-50 $\mu \mathrm{mol}$ photon per $\mathrm{m}^{2}$ per second in a 12 -h light/dark cycle. Aliquots of the cultures were removed on the 7th and 60th days of incubation. From the aliquots, quantities of MAF cells were counted using a light microscope (BX43, Olympus). The amount of soluble phosphorus in the media was also concurrently measured by the above described method.

\section{Statistical analysis}

All the values for phosphate solubilization and growth promotion assay were expressed as means of three experimental data. These data were subjected to one-way ANOVA at $P<0.05$ and $P<0.01$ using SPSS software version 17 (SPSS, Beijing, China).

\section{RESULTS AND DISCUSSION}

\section{Phenotypic characteristics}

Cells of strain JXJ CY $01^{\mathrm{T}}$ were observed to be Gram-staining-positive and non-endospore forming. Cells are short rods with a size of $0.4-0.6 \times 0.6-1.1 \mu \mathrm{m}$ (Figure 1). Growth of strain JXJ CY $01^{\mathrm{T}}$ was observed at $4-45^{\circ} \mathrm{C}, \mathrm{pH} 6.0-8.0$ and $0-5 \%(\mathrm{w} / \mathrm{v}) \mathrm{NaCl}$, with optimal growth at $25-28^{\circ} \mathrm{C}, \mathrm{pH} 7.0-8.0$ and $0-2 \%(\mathrm{w} / \mathrm{v}) \mathrm{NaCl}$. The isolate was found to be positive for catalase and oxidase tests. Other differential phenotypic characteristics of strain JXJ CY $01^{\mathrm{T}}$ and the related type strains M. marinilacus JCM $16546^{\mathrm{T}}$ and M. paludicola JCM $14308^{\mathrm{T}}$ are listed in Table 1, and the detailed characteristics of the proposed novel strain are given in the species description.

\section{Chemotaxonomic characteristics}

Strain JXJ CY $01^{\mathrm{T}}$ contained L-ornithine as the diagnostic amino acid along with alanine, aspartic acid, glutamic acid and glycine in the peptidoglycan, and mannose, rhamnose, glucose, galactose, arabinose and fucose as whole-cell sugars. The polar lipids detected were diphosphatidylglycerol, phosphatidylglycerol, an unidentified glycolipid and two unidentified phospholipids (see Supplementary Figure S1). The respiratory menaquinones consisted of MK-12 (70.1\%), MK-11 (21.2\%) and MK-12 $\left(\mathrm{H}_{4}\right)$ $(8.7 \%)$. The fatty acid methyl ester profiles were anteiso- $\mathrm{C}_{15: 0}$

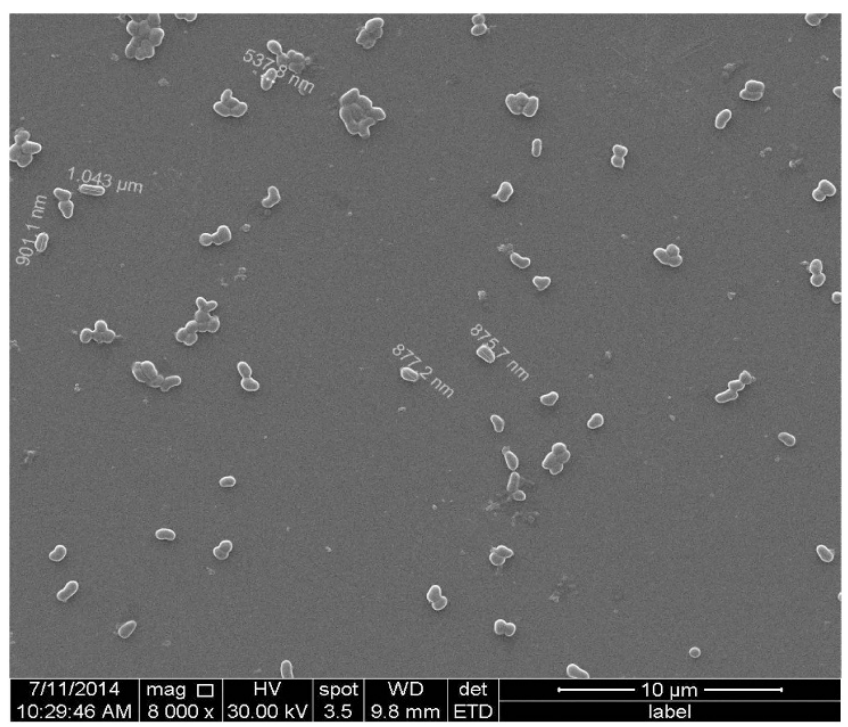

Figure 1 Scanning electron micrograph of strain JXJ $\mathrm{CY} \mathrm{Ol}^{\top}$ after cultured in ISP 2 media for 3 days. A full color version of this figure is available at The Journal of Antibiotics journal online. 
Table 1 Differential characteristics of strain JXJ $\mathrm{CY} 01^{\top}$ and members of the genus Microbacterium

\begin{tabular}{|c|c|c|c|}
\hline & 1 & 2 & 3 \\
\hline $\mathrm{G}+\mathrm{C}$ content $(\mathrm{mol} \%)$ & 70.4 & 71.6 & 66.5 \\
\hline $\mathrm{NaCl}$ tolerance $(\% \mathrm{w} / \mathrm{v})$ & $0-5$ & $0-9$ & $0-8$ \\
\hline Temperature for growth $\left({ }^{\circ} \mathrm{C}\right)$ & $4-45$ & $4-37$ & $4-40$ \\
\hline $\mathrm{pH}$ range for growth & $6-8$ & $6-9$ & $6-9$ \\
\hline Tween 80 hydrolysis & - & - & + \\
\hline Starch hydrolysis & + & - & - \\
\hline \multicolumn{4}{|l|}{ Utilization of } \\
\hline D-Sorbitol & + & - & - \\
\hline D-Ribose & + & - & - \\
\hline D-Xylitol & + & - & + \\
\hline D-Melibiose & - & + & - \\
\hline L-Cysteine & - & + & + \\
\hline L-Histidine & - & + & + \\
\hline L-Valine & - & + & + \\
\hline D-Arabitol & + & - & - \\
\hline D-Arabinose & + & + & - \\
\hline \multicolumn{4}{|c|}{ Acid produced from (API $50 \mathrm{CH})$} \\
\hline D-Arabinose & - & - & + \\
\hline L-Arabinose & - & + & - \\
\hline D-Galactose & - & + & - \\
\hline D-Glucose & - & + & + \\
\hline Salicin & + & - & - \\
\hline Sucrose & + & - & + \\
\hline Trehalose & - & + & - \\
\hline D-Turanose & + & - & + \\
\hline \multicolumn{4}{|l|}{ API 20 NE results } \\
\hline Adipic acid & - & + & + \\
\hline Citric acid & - & + & - \\
\hline Gelatin & + & - & - \\
\hline Malate & - & - & + \\
\hline Mannose & - & + & + \\
\hline
\end{tabular}

Abbreviations: +, positive; -, negative.

Strains: 1 , JXJ CY $01^{\top} ; 2$, M. marinilacus JCM 16546T; 3, M. paludicola JCM $14308^{\top}$. All data are from this study.

(42.9\%), iso- $\mathrm{C}_{16: 0}(20.1 \%)$, anteiso- $\mathrm{C}_{17: 0}(16.9 \%)$, iso- $\mathrm{C}_{15: 0}(11.5 \%)$, iso- $\mathrm{C}_{17: 0}(3.3 \%)$, iso- $\mathrm{C}_{14: 0}$ iso $(2.1 \%)$, anteiso- $\mathrm{C}_{15: 1} \mathrm{~A}(1.7 \%)$ and $\mathrm{C}_{16: 0}$ $(0.9 \%)$ (Supplementary Table S1). The $\mathrm{G}+\mathrm{C}$ content of the genomic DNA was determined to be $70.4 \mathrm{~mol} \%$.

\section{Phylogenetic characteristics}

Analysis of the almost-complete $16 \mathrm{~S}$ rRNA gene sequence (1538 bp) revealed that strain JXJ CY $01^{\mathrm{T}}$ is a member of the genus Microbacterium. It shared $16 \mathrm{~S}$ rRNA gene sequence similarities of

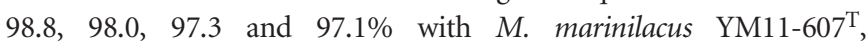
M. paludicola $\mathrm{US}^{\mathrm{T}} 5^{\mathrm{T}}$, M. sediminicola $\mathrm{YM} 10-847^{\mathrm{T}}$ and $M$. bareri DSM $20145^{\mathrm{T}}$, and less than $97 \%$ with other members of the genus Microbacterium. The strain formed a relatively stable clade with strains M. marinilacus YM1 $1-607^{\mathrm{T}}$ and M. paludicola $\mathrm{US}^{\mathrm{T}} 5^{\mathrm{T}}$ in the phylogenetic dendrograms based on 16S rRNA gene sequence (Figure 2 and Supplementary Figure S2). DNA-DNA hybridization experiments showed that strain JXJ CY $01^{\mathrm{T}}$ displayed a DNA-DNA reassociation values of $53.5 \pm 1.4$ and $53.8 \pm 2.1 \%$ with $M$. marinilacus JCM $16546^{\mathrm{T}}$ and M. paludicola JCM $14308^{\mathrm{T}}$, respectively (Supplementary Table
S2), thereby indicating that the whole genomic DNA relatedness values are below the $70 \%$ delineating limit for species identification. ${ }^{34}$

The genotypic and phenotypic features described above suggest that strain JXJ CY $01^{\mathrm{T}}$ could be clearly distinguished from its closest phylogenetic relatives. Besides low DNA-DNA relatedness with the closely related phylogenetic strains, the strain is also distinguished from them by several phenotypic properties as listed in Table 1. Based on the above findings, strain JXJ CY $01^{\mathrm{T}}$ is considered to represent a novel species of the genus Microbacterium, for which the name Microbacterium lacusdiani sp. nov. is proposed.

\section{Phosphate solubilization}

The cultures in PG media on incubation for 6 days were turbid, indicating that the strains grew well in the phosphate-solubilizing media. The content of soluble phosphorus in the media containing $\mathrm{Ca}_{3}$ $\left(\mathrm{PO}_{4}\right)_{2}$ and $\mathrm{L}-\alpha$-phosphatidylcholine increased from $0.8 \pm 0.1$ and $1.2 \pm 0.0 \mathrm{mgl}^{-1}$ at day 0 to $45.7 \pm 0.8$ and $5.8 \pm 0.4 \mathrm{mg} \mathrm{l}^{-1}$, respectively, after 6 days incubation. However in the control, there was no increase in the amount of soluble phosphorus in $\mathrm{Ca}_{3}\left(\mathrm{PO}_{4}\right)_{2}-$ containing medium while slight increase of $1.6 \pm 0.1 \mathrm{mgl}^{-1}$ was observed in the one containing $\mathrm{L}-\alpha$-phosphatidylcholine $(P<0.01)$. The results indicated that strain JXJ CY $01^{\mathrm{T}}$ could dissolve insoluble phosphorus effectively.

Effect on the growth of MAF by co-culturing with strain JXJ CY $01^{\mathrm{T}}$ under in vitro condition

The effect of cell density of MAF by co-inoculating with different inoculums of strain JXJ CY $01^{\mathrm{T}}$ on three different media is shown in Table 2. In the absence of any co-inoculums, a 10-fold increase in the cell densities of MAF was observed on day 60 as compared with day 7 when the phosphate source is $\mathrm{KH}_{2} \mathrm{PO}_{4}$ while a little lesser than 10-fold in medium containing insoluble phosphate (Table 2). This result indicated that soluble phosphorus is more favorable for the growth of MAF. Additionally, MAF growth was better off using both insoluble inorganic and organic phosphate when co-cultured with strain JXJ CY $01^{\mathrm{T}}$ (Table 2). Inoculum size also gave varying effect on the growth promotion activities. Cell density of MAF was higher with an inoculum size of $0.2 \times 10^{9} \mathrm{CFU} \mathrm{ml}^{-1}$ of strains JXJ CY $01^{\mathrm{T}}$ on day 7 in medium containing $\mathrm{KH}_{2} \mathrm{PO}_{4}$. Similar pattern was observed in media containing $\mathrm{L}-\alpha$-phosphatidylcholine. On the contrary, higher MAF was observed with a higher inoculum density of strain JXJ CY $01^{\mathrm{T}}$ in medium containing $\mathrm{Ca}_{3}\left(\mathrm{PO}_{4}\right)_{2}$ (Table 2 ). The cell density of MAF in both HGZ and modified HGZ media on day 60 increased with the increase in bacterial inoculums density (Table 2).

The content of soluble phosphorus increased significantly in modified HGZ media after inoculation of strain JXJ CY $01^{\mathrm{T}}$ (Figure 3; $P<0.05, P<0.01$ ). This may partly contribute to the enhanced growth rates of MAF in modified HGZ media. Despite the fact that HGZ media have adequate soluble phosphorus for growth of MAF, co-inoculation of JXJ CY $01^{\mathrm{T}}$ increased the cell density of MAF significantly (Table 2). This result indicated apart from phosphate solubilization, additional factors may be involved for growth promotion of MAF by strain JXJ CY $01^{\mathrm{T}}$. Similar findings have been reported by other research groups working on cyanobacterial mat. Zhao et al. ${ }^{35}$ found that Actinobacteria strain Gordonia sp. txj1302RI produce unknown substances that promote the growth of Microcystis. de-Bashan et al. ${ }^{36}$ reported that Azospirillum spp. produce indole-3-acetic acid, thereby promoting the growth of Chlorella vulgaris. Microbacterium azadirachtae AI-S262 ${ }^{\mathrm{T}}$ was reported as a plant-growth-promoting actinobacterium by mechanisms of indole-3-acetic acid production and phosphorus solubilization. ${ }^{37}$ 


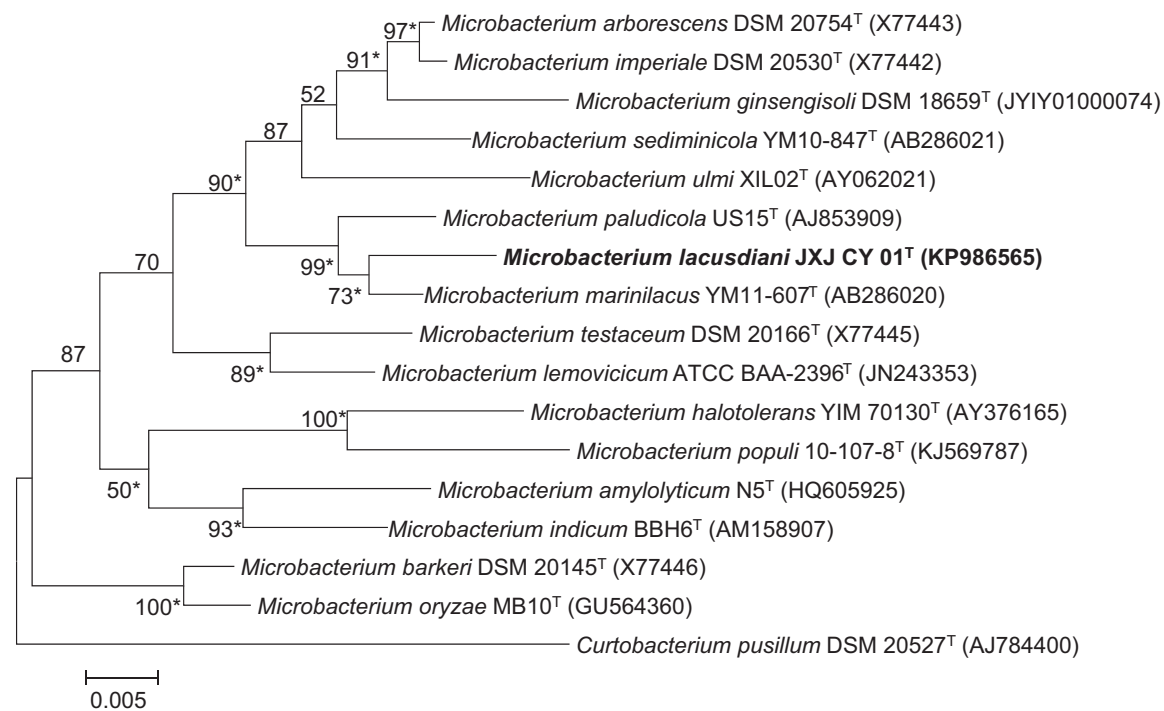

Figure 2 Neighbor-joining phylogenetic tree based on 16S rRNA gene sequences of strain JXJ $C Y 01^{\top}$ and its closely relative species of the genus Microbacterium. The strain Curtobacterium pusillum DSM $20527^{\top}$ was used as the outgroup. Bootstrap values (expressed as percentages of 1000 replications) $>50 \%$ are shown at the nodes. Asterisks indicate branches that were conserved using the maximum-parsimony and maximum-likelihood methods. Bar, 0.005 substitutions per nucleotide position.

Table 2 Cell density (mean \pm s.d.; $n=3$ ) of MAF after co-culturing with strain JXJ CY $01^{\top}$

\begin{tabular}{|c|c|c|c|c|c|c|}
\hline$A$ & $a^{*}$ & $b^{*}$ & $c^{*}$ & $a^{*}$ & $b^{*}$ & $c^{*}$ \\
\hline 0.0 & $9.03 \pm 0.33$ & $6.85 \pm 0.31$ & $6.72 \pm 0.42$ & $9.87 \pm 0.32$ & $5.58 \pm 0.22$ & $6.38 \pm 0.37$ \\
\hline 0.2 & $11.40 \pm 0.48^{* *}$ & $7.83 \pm 0.11^{* *}$ & $9.35 \pm 0.44^{* *}$ & $10.34 \pm 0.60$ & $10.47 \pm 0.51^{* *}$ & $9.91 \pm 0.40^{* *}$ \\
\hline 1.0 & $10.63 \pm 0.67^{*}$ & $8.33 \pm 0.35^{* *}$ & $8.25 \pm 0.47^{*}$ & $11.64 \pm 0.73^{*}$ & $14.04 \pm 0.67^{* *}$ & $11.07 \pm 0.55^{* *}$ \\
\hline 5.0 & $9.35 \pm 0.45$ & $9.40 \pm 0.22^{* *}$ & $7.25 \pm 0.32$ & $13.74 \pm 0.53^{* *}$ & $16.16 \pm 0.80^{* *}$ & $15.65 \pm 0.99^{* *}$ \\
\hline
\end{tabular}

Statistical comparisons with the controls were made using ANOVA ( $\left.{ }^{*} P<0.05,{ }^{* *} P<0.01\right)$. A, initial cell density of JXJ CY $01 \mathrm{~T}\left(\times 10^{9} \mathrm{CFU} \mathrm{mI}{ }^{-1}\right)$.

*Phosphate source in $\mathrm{HGZ}$ medium: $\mathrm{a}, \mathrm{KH}_{2} \mathrm{PO}_{4} ; \mathrm{b}, \mathrm{Ca}_{3}\left(\mathrm{PO}_{4}\right)_{2} ; \mathrm{c}, \mathrm{I}-\alpha-$ phosphatidylcholine.
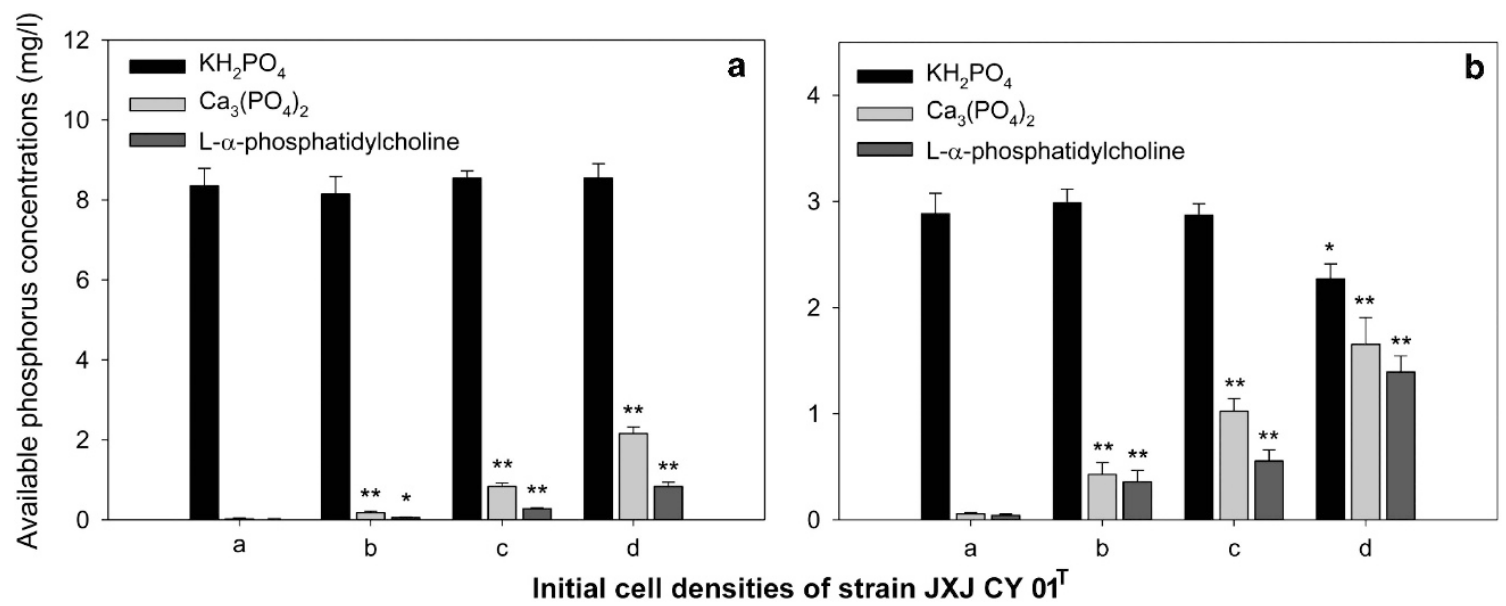

Figure 3 Soluble phosphorus concentrations in HGZ and modified HGZ media after co-culturing of MAF and JXJ CY $01^{\top}$ for day 7 (a) and day 60 (b). a,b,c and d represents initial cell densities of JXJ CY $01^{\top}$ corresponding to $0 \times 10^{9}, 0.2 \times 10^{9}, 1 \times 10^{9}$ and $5 \times 10^{9} \mathrm{CFU} \mathrm{ml}^{-1}$, respectively. Statistical comparisons with the controls were made by ANOVA $\left({ }^{*} P<0.05,{ }^{* *} P<0.01\right)$.

Description of Microbacterium lacusdiani sp. nov.

Microbacterium lacusdiani (la.cus.di.a'ni. L. gen. n. lacus, of a lake; N.L. gen. n. diani, of Dian; N.L. gen. n. lacusdiani, of Dian lake).
Cells are aerobic, Gram-staining positive, non-spore-forming and short rods $(0.4-0.6 \times 0.6-1.1 \mu \mathrm{m})$. Growth is observed at $4-45^{\circ} \mathrm{C}, \mathrm{pH}$ $6.0-8.0$ and $0-5 \%(\mathrm{w} / \mathrm{v}) \mathrm{NaCl}$, with optimal growth at $25-28^{\circ} \mathrm{C}$, $\mathrm{pH} 7.0-8.0$ and $0-2 \%(\mathrm{w} / \mathrm{v}) \mathrm{NaCl}$. Utilizes D-arabinose, D-arabitol, 
D-(+)-cellobiose, D-fructose, D-galactose, D-glucose, D-glycerol, L-lactose, D-mannitose, D-ribose, sodium acetate, D-sorbitol, sucrose, D-trehalose, D-xylitol and D-xylose as sole carbon sources, and L-alanine, L-aspartic acid, L-glutamic acid, L-glutamine, glycine, L-leucine, L-isoleucine, L-methionine, L-lysine, L-tyrosine, L-tryptophan, L-proline, L-serine and hypoxanthine as sole nitrogen sources. Does not utilize dulcitol, D-mannose, D-melibiose, D-myo-inositol, D-raffinose, L-rhamnose, sodium propionate, L-cysteine, L-histidine, L-phenylalanine, L-valine or L-threonine as either sole carbon or nitrogen sources. Positive in catalase and oxidase tests but negative in milk coagulation, milk peptonization, nitrate reduction, methyl red, Voges-Prokauer and $\mathrm{H}_{2} \mathrm{~S}$ production tests. Hydrolyzes gelatin and starch, but not casein or cellulose. Acid is produced from salicin, starch, sucrose and D-turanose (API 50CH). The cell wall peptidoglycan contains L-ornithine along with whole-cell sugars of mannose, rhamnose, glucose, galactose, arabinose and fucose. Polar lipids consist of diphosphatidylglycerol, phosphatidylglycerol, an unidentified glycolipid and two unidentified phospholipids. The major menaquinones were MK-11 and MK-12. Major fatty acids are anteiso- $\mathrm{C}_{15: 0}$, iso- $\mathrm{C}_{16: 0}$, anteiso- $\mathrm{C}_{17: 0}$ and iso- $\mathrm{C}_{15: 0}$. The $\mathrm{G}+\mathrm{C}$ content of the genomic DNA of the type strain is $70.4 \mathrm{~mol} \%$. It solubilizes insoluble form of both inorganic and organic phosphate.

The type strain, JXJ CY $01^{\mathrm{T}}\left(=\mathrm{KCTC} 29655^{\mathrm{T}}=\mathrm{DSM} 29188^{\mathrm{T}}\right)$, was isolated from mucilaginous sheath of $M$. aeruginosa FACHB-905, collected from Lake Dianchi, Yunnan province, China. The 16S rRNA gene sequence of strain JXJ CY $01^{\mathrm{T}}$ has been deposited in GenBank under the accession number KP986565.

\section{CONFLICT OF INTEREST}

The authors declare no conflict of interest.

\section{ACKNOWLEDGEMENTS}

This research was supported by funds from Natural Science Foundation of China (No 31060010), Environmental Conservation Department of Jiangxi Province of China (No. JXHBKJ2013-14) and Program of Jiujiang University (No 201511). W-JL was also supported by Guangdong Province Higher Vocational Colleges \& Schools Pearl River Scholar Funded Scheme (2014).

1 Pan, G., Zhang, M. M., Chen, H., Zou, H. \& Yan, H. Removal of cyanobacterial blooms in Taihu Lake using local soils. I. Equilibrium and kinetic screening on the flocculation of Microcystis aeruginosa using commercially available clays and minerals. Environ. Pollut. 141, 195-200 (2006)

2 Liu, Y. M. et al. Analysis of paralytic shellfish toxins in Aphanizomenon DC-1 from Lake Dianchi, China. Environ. Toxicol. 21, 289-295 (2006).

3 Liu, L. P. Characteristics of blue algal bloom in Dianchi Lake and analysis on its cause. Res. Environ. Sci. 12, 36-37 (1999).

4 Dziallas, C. \& Grossart, H. P. Temperature and biotic factors influence bacterial communities associated with the cyanobacterium Microcystis sp. Environ. Microbiol. 13, 1632-1641 (2011).

5 Parveen, B. et al. Bacterial communities associated with Microcystis colonies differ from free-living communities living in the same ecosystem. Environ. Microbiol. Rep. 5, 716-724 (2013).

6 Shi, L. M., Cai, Y. F., Kong, F. X. \& Yu, Y. Specific association between bacteria and buoyant Microcystis colonies compared with other bulk bacterial communities in the eutrophic Lake Taihu, China. Environ. Microbiol. Rep. 4, 669-678 (2012).

7 Casamatta, D. \& Wickstrom, C. Sensitivity of two distinct bacterioplankton communities to exudates from the cyanobacterium Microcystis aeruginosa. Microb. Ecol. 41, 64-73 (2000).
8 Deng, J. et al. Effect of attached bacteria of carbonic anhydrase on the growth of Microcystis aeruginosa. J. Lake Sci. 24, 429-435 (2012).

9 Jürgens, K. \& Güde, H. The potential importance of grazing-resistant bacteria in planktonic systems. Mar. Ecol. Prog. Ser. 112, 169-188 (1994).

$10 \mathrm{Niu}, \mathrm{Y}$. et al. Phytoplankton community succession shaping bacterioplankton community composition in Lake Taihu, China. Water Res. 45, 4169-4182 (2011).

11 Shi, L. M. et al. Phylogenetic diversity and specificity of bacteria associated with Microcystis aeruginosa and other cyanobacteria. J. Environ. Sci. 21, 1581-1590 (2009).

12 Yang, L. Y. \& Xiao, L. Outbrust, Jeopardize and Control of Cyanobacterial Bloom in Lakes 212 (Science Press, Beijing, 2010).

13 Zhang, B. H. et al. An antialgal compound produced by Streptomyces jiujiangensis JXJ 0074'T. Appl. Microbiol. Biotechnol. 99, 7673-7683 (2015).

14 Shirling, E. B. \& Gottlieb, D. Methods for characterization of Streptomyces species. Int. J. Syst. Bacteriol. 16, 313-340 (1966).

$15 \mathrm{Xu}$, P. et al. Naxibacter alkalitolerans gen. nov., sp. nov., a novel member of the family Oxalobacteraceae isolated from China. Int. J. Syst. Evol. Microbiol. 55, 1149-1153 (2005).

16 Kovacs, N. Identification of Pseudomonas pyocyanea by the oxidase reaction. Nature 178, 703-704 (1956).

17 Goodfellow, M. Numerical taxonomy of some nocardioform bacteria. J. Gen. Microbiol. 69, 33-80 (1971).

18 Williams, S. T. et al. Numerical classification of Streptomyces and related genera. J. Gen. Microbiol. 129, 1743-1813 (1983).

19 Hasegawa, T., Takizaea, M. \& Tanida, S. A rapid analysis for chemical grouping aerobic actinomycetes. J. Gen. Appl. Microbiol. 29, 319-322 (1983).

20 Tang, S. K. et al. Zhihengliuella alba sp. nov., and emended description of the genus Zhihengliuella. Int. J. Syst. Evol. Microbiol. 59, 2025-2032 (2009).

21 Minnikin, D. E., Collins, M. D. \& Goodfellow, M. Fatty acid and polar lipid composition in the classification of Cellulomonas, Oerskovia and related taxa. J. Appl. Bacteriol. 47, 87-95 (1979).

22 Collins, M. D. \& Jones, D. Lipids in the classification and identification of coryneform bacteria containing peptidoglycan based on 2,4-diaminobutyric acid. J. Appl. Bacteriol. 48, 459-470 (1980).

23 Collins, M. D., Pirouz, T., Goodfellow, M. \& Minnikin, D. E. Distribution of menaquinones in actinomycetes and corynebacteria. J. Gen. Microbiol. 100, 221-230 (1977).

24 Kroppenstedt, R. M. Separation of bacterial menaquinones by HPLC using reverse phase (RP18) and a silver loaded ion exchanger as stationary phases. J. Liq. Chromatogr. 5, 2359-2387 (1982).

25 Sasser, M. Identification of Bacteria by Gas Chromatography of Cellular Fatty Acids, MIDI Technical Note 101 (MIDI, Newark, DE, 2001).

26 Mesbah, M., Premachandran, U. \& Whitman, W. B. Precise measurement of the $\mathrm{G}+\mathrm{C}$ content of deoxyribonucleic acid by high-performance liquid chromatography. Int. J. Syst. Bacteriol. 39, 159-167 (1989).

27 Thompson, J. D., Gibson, T. J., Plewniak, F., Jeanmougin, F. \& Higgins, D. G. The CLUSTAL $X$ windows interface: flexible strategies for multiple sequence alignment aided by quality analysis tools. Nucleic Acids Res. 25, 4876-4882 (1997).

28 Saitou, N. \& Nei, M. The neighbor-joining method: a new method for reconstructing phylogenetic trees. Mol. Biol. Evol. 4, 406-425 (1987).

29 Felsenstein, J. Evolutionary trees from DNA sequences: a maximum likelihood approach. J. Mol. Evol. 17, 368-376 (1981).

30 Fitch, W. M. Toward defining the course of evolution: minimum change for a specific tree topology. Syst. Zool. 20, 406-416 (1971).

31 Tamura, K. et al. MEGA5: Molecular evolutionary genetics analysis using maximum likelihood, evolutionary distance, and maximum parsimony methods. Mol. Biol. Evol. 28, 2731-2739 (2011).

32 Felsenstein, J. Confidence limits on phylogenies: an approach using the bootstrap. Evolution 39, 783-791 (1985).

33 Ezaki, T., Hashimoto, Y. \& Yabuuchi, E. Fluorometric deoxyribonucleic aciddeoxyribonucleic acid hybridization in microdilution wells as an alternative to membrane filter hybridization in which radioisotopes are used to determine genetic relatedness among bacterial strains. Int. J. Syst. Bacteriol. 39, 224-229 (1989).

34 Wayne, L. G. et al. International Committee on Systematic Bacteriology. Report of the ad hoc committee on reconciliation of approaches to bacterial systematic. Int. J. Syst. Bacteriol. 37, 463-464 (1987).

35 Zhao, G. Y. et al. The importance of bacteria in promoting algal growth in eutrophic lakes with limited available phosphorus. Ecol. Eng. 42, 107-111 (2012).

36 de-Bashan, L. E., Antoun, H. \& Bashan, Y. Involvement of indole-3-acetic-acid produced by the growth-promoting bacterium Azospirillum spp. in promoting growth of Chlorella vulgaris. J. Phycol. 44, 938-947 (2008).

37 Madhaiyan, M. et al. Microbacterium azadirachtae sp. nov., a plant growth-promoting actinobacterium isolated from the rhizoplane of neem seedlings. Int. J. Syst. Evol. Microbiol. 60, 1687-1692 (2010).

Supplementary Information accompanies the paper on The Journal of Antibiotics website (http://www.nature.com/ja) 